Journal of Applied Pharmaceutical Science Vol. 6 (02), pp. 124-129, February, 2016

Available online at http://www.japsonline.com

DOI: $10.7324 /$ JAPS.2016.60219

ISSN 2231-3354 (cc) BY-NC-SA

\title{
Antioxidant, analgesic and anti-inflammatory activities of the leafy stems of Waltheria indica L. (Sterculiaceae)
}

\author{
Mouhibatou Nadège YOUGBARE-ZIEBROU ${ }^{1 *}$, Marius LOMPO ${ }^{1}$, Noufou OUEDRAOGO ${ }^{1}$, Boubacar YARO ${ }^{1}$, \\ Innocent Pierre GUISSOUN ${ }^{1,2}$ \\ ${ }^{1}$ Département de médecine et de pharmacopée traditionnelle (IRSS/CNRST) 03 B.P. 7192 Ouagadougou 03, Burkina Faso. ${ }^{2}$ Laboratoire de pharmacologie \\ et de Toxicologie, UFR/SDS Université de Ouagadougou 03 B.P.7021 Ouagadougou Burkina Faso.
}

\begin{tabular}{ll}
\hline ARTICLE INFO & ABSTRACT \\
\cline { 3 - 4 } $\begin{array}{l}\text { Article history: } \\
\text { Received on: } 23 / 10 / 2015 \\
\text { Revised on: } 05 / 12 / 2015 \\
\text { Accepted on: } 24 / 12 / 2015 \\
\text { Available online: } 27 / 02 / 2016\end{array}$ & $\begin{array}{l}\text { Aim of the study: The existence of numerous side effects following the use of anti inflammatory drugs has led to } \\
\text { the present study about Waltheria indica (Sterculiaceae), prescribed in the treatment of many inflammatory } \\
\text { diseases component to discover phytomedicines secondary effects mitigated. } \\
\text { Materials and methods: The chemical principles have been demonstrated by test characterization in liquid } \\
\text { medium according the method of Ciulei (1949). In vivo, the model of edema induced by carrageenan to cause } \\
\text { inflammation and the model of acetic acid induced pain were used to assess the anti-inflammatory and analgesic } \\
\text { activities of the extract. In vitro, the effects of the aqueous extract on the DPPH }{ }^{\circ \circ} \text { radical, the lipoxygenase and } \\
\text { Key words: }\end{array} \quad \begin{array}{l}\text { lipid peroxidation has been demonstrated. } \\
\text { Results: Phytochemical study of leafy stems of the plant showed the presence of tannins, flavonoids, sterols, } \\
\text { indica L., Inflammation, } \\
\text { Analgesia, Anti-oxidants. } \\
\text { anti- edematous effects of the analgesic of the plant. In vitro, the results revealed the aqueous extract of } W . \text { indica } \\
\text { inhibited the radical of DPPH }{ }^{\circ \circ} \text {, the lipoxygenase and the lipid peroxidation. } \\
\text { Conclusion: The presence of chemical compounds and biological properties obtained justify the contribution of } \\
\text { the plant in traditional medicine for the treatment of diseases with inflammatory component. }\end{array}$ \\
\hline
\end{tabular}

\section{INTRODUCTION}

Inflammation is a defensive response of body against all aggression such as pathogens (bacteria, virus, fungi, parasites) or others stimuli. The inflammatory process involves the release of pro-inflammatory cytokines, prostaglandins and the formation of reactive oxygen species (ROS). Excessive of these inflammatory mediators lead to maintain inflammation and induce a chronic inflammation (Philpott et Ferguson, 2004). Chronic inflammation is considered as a critical factor in many human diseases including cancer, obesity, type II diabetes, cardiovascular diseases, neurodegenerative diseases and aging (Santangelo et al., 2007). Inflammation involves the metabolism of arachidonic acid which can be catalyzed by enzymes such as

\footnotetext{
* Corresponding Author

Email: nnadouz@yahoo.fr, Phone: +22670272317
}

cyclooxygenase (COX) and lipoxygenase (LOX). Leukotrienes and prostaglandins (PG) are inflammatory mediators generated from arachidonic acid respectively by lipoxygenase and cyclooxygenase (Cox1 and 2). The lipoxygenase pathway generates products that are important in asthma, allergy, and inflammation (Bigby, 2002). Non-steroidal anti-inflammatory drugs (NSAIDs) used to treat inflammation, have as targets COX 1 and 2 (Dwyer, 2004; Botting, 2006). The long-term use of non steroidal anti-inflammatory drugs has many side effects including gastrointestinal erosion, peptic ulcers, nephrotoxicity, leukopenia, allergic manifestations. To overcome these effects, natural substances, such medicinal plant are a way to discover news antiinflammatory drugs. Waltheria indica Linn. (Sterculiaceae), is used in Burkina Faso folk medecine. Leaves, bark, roots or the whole plant are used against swelling, toothache, colic, rheumatism, ear infections, asthma, cough, diarrhea, dysentery, conjunctivitis, wounds, abscess (Flatie et al., 2009; Adjanohoun et al., 1989; Ruffo, 1991; Zerbo et al., 2007, Zongo, 2013). 
Miyashiro et al. (1994) showed that aqueous and methanolic extracts of Waltheria indica L. had a significant inhibition of HIV-1 protease. However, stems with leaves of $W$. indica have not been many pharmacological studies. The objective of this study was to investigate chemical and pharmacotoxicological evaluation by the anti-inflammatory, analgesic, antioxidant and acute toxicity of aqueous extract of stems with leaves of $W$. indica to justify the traditional use of the plant.

\section{MATERIALS AND METHODS}

\section{Plant material}

The leafy stems of Waltheria indica were collected in May 2009 at Pissy, located in the west side of the city of Ouagadougou (Burkina Faso). They were washed, dried to protect from light and dust. The dried bodies were ground to obtain fine powders. The powder was packed in plastic bags and stored protected from dust, moisture and heat.

\section{Animals}

NMRI mice male and female $(25-32 \mathrm{~g})$ were fed with pellets containing $29 \%$ protein. The room temperature was maintained at $22 \pm 2{ }^{\circ} \mathrm{C}$ with the $12 \mathrm{~h}$ light/ $12 \mathrm{~h}$ dark cycle. The tests were performed strictly in accordance with the guidelines for use of laboratory animals (Zimmermann, 1983).

\section{Chemicals}

All chemicals used were analytical grade. Carrageenan, 2, 2-diphenyl-1-picrylhydrazyl (DPPH), acetic acid, dimethyl sulfoxide (DMSO) was purchase from Sigma (St Louis, USA). Sodium chloride, lysine acetylsalicylate (Aspégic ${ }^{\circledR}$, Sanofi Aventis France); Paracetamol (Rotexmedicain Germany) were also used in this work.

\section{Methods}

\section{Extraction}

Fifty grams $(50 \mathrm{~g})$ of powder of stems with leaves of $W$. indica were extracted by decoction using $500 \mathrm{~mL}$ water during 30 min. The aqueous solution was filtered and then centrifuged at 10 $000 \mathrm{trs} / \mathrm{min}$ for five minutes. The supernatant was lyophilized touse in the various tests.

\section{Carrageenan-induced paw edema test}

The method of Winter (1962) was used to assess the antiedema effect of aqueous extract of Waltheria indica. Six groups of 6 mice (male and female) received respectively, the extract of $W$. indica $(25,100,200$ and $300 \mathrm{mg} / \mathrm{kg})$; Aspegic $(300 \mathrm{mg} / \mathrm{kg} \mathrm{bw})$ and sterile distilled water $(5 \mathrm{~mL} / \mathrm{kg})$. A volume of $50 \mu \mathrm{L}$ of a $1 \%$ carrageenin solution $(0.9 \% \mathrm{NaCl})$ was injected into the foot pad of the right hind paw of mice, one hour after substance administration (aqueous extract, sterile distilled water and Aspégic). The volume of edema was measured 1 hour prior to, and 1, 3, and 5 hours after carrageenan injection using a plethysmometer (Ugo Basile 7140 APALEX).
The anti-edema effect was evaluated by using the following formula:

$$
\text { Inhibition } \%=\frac{(V t-V o) c-(V t-V o) t}{(V t-V o) c} \times 100
$$

$\mathrm{Vt}$ : volume of the treated paw at time $(\mathrm{t}), \mathrm{Vo}=$ volume of the paw before injection of carrageenan; $(\mathrm{Vt}-\mathrm{Vo}) \mathrm{c}$ : the mean difference of the volume increase of the paw of mice and the control group $(\mathrm{Vt}$ Vo)t: represents the average difference of the volume increase of the paw of mice treated batches.

\section{Acetic acid-induced writhing test}

Acetic acid injected into the peritoneum of the mouse has been used to induce pain (Koster, 1959). Five groups of six mice (females and male) were used. The mice received orally extracts of $W$. indica $(100,200,300 \mathrm{mg} / \mathrm{kg}$ bw), paracetamol $(150 \mathrm{mg} / \mathrm{kg}$ bw) and distilled water $(5 \mathrm{~mL} / \mathrm{kg} \mathrm{bw}) 1 \mathrm{~h}$ before acetic acid solution injection. The injection of acetic acid $(0.6 \%)$ provoked abdominal contorsions which were recorded 5 min after injection and during $15 \mathrm{~min}$. The analgesic effect was expressed as reduction percentage of contorsions by using the following formula:

$$
\% \text { Inhibition }=[(\mathrm{Nte}-\mathrm{Nt}) / \mathrm{Nte}] \times 100
$$

With Nte: number of contortion of the negative control and $\mathrm{Nt}$ : number of contortion batch test or the positive control.

\section{Antioxidant activity: DPPH assay}

The DPPH (1-1, diphenylpicrylhydrazyl) method described by Kim et al. (2003) was used to evaluate the antioxidant activity of the aqueous extract of the plant. For this purpose, $10 \mu \mathrm{L}$ of aqueous extract of $W$. indica (dissolved in DMSO from $21 \mathrm{mg} / \mathrm{mL}$ to $1,28 \mu \mathrm{g} / \mathrm{mL}$ ) were added to $200 \mu \mathrm{L}$ of DPPH solution $(0.04 \mathrm{mg} / \mathrm{mL})$ in a microplate of 96 wells. The mixture was incubated at $37^{\circ} \mathrm{C}$ for 30 minutes. After incubation the absorbance were recorded at $492 \mathrm{~nm}$. All tests were performed in triplicate for each concentration of standard or sample from which the inhibitory concentration $\mathrm{IC}_{50}$ was derived by the formula:

Inhibition of DPPH $(\%)=(1-($ ODtest/ ODwhite $)) \times 100$. DO: optic density

\section{Test of lipoxygenase inhibition}

Anti-inflammatory activity in vitro was assessed by the spectrophotometric method developed by Maltherud and Rydland (2009). $400 \mu \mathrm{L}$ of lipoxygenase enzyme (167 U/mL) was mixed with $100 \mu \mathrm{L}$ of the aqueous extract at a concentration of $50 \mu \mathrm{g} / \mathrm{mL}$ and incubated for 2 minutes at $25^{\circ} \mathrm{C}$. Five hundred microliters $(500 \mu \mathrm{L})$ of the solution of linoleic acid substrate $(250 \mu \mathrm{M})$ were added to the mixture to initiate the reaction. The change in absorbance was monitored at $234 \mathrm{~nm}$ for 2 minutes. All tests were performed in triplicate. The hydrocortisone was used as reference products. The inhibitory capacity of the extract was determined using the formula:

$$
\% \text { Inhibition }=(\mathrm{S}-\mathrm{E}) / \mathrm{S} \times 100
$$


E: enzyme activity without inhibitor; S: enzyme activity in the presence of the sample to be tested.

\section{Test of lipid peroxidation inhibition}

The inhibitory effect of extract on lipid peroxidation in vitro was carried out by the method of $\mathrm{Su}$ et al. (2009). A volume of $0.2 \mathrm{~mL}$ of standard or extract at a concentration of $1.5 \mathrm{mg} / \mathrm{mL}$, $1 \mathrm{~mL}$ of rat liver homogenate $1 \%(100 \mathrm{~mL}$, containing 1 gram of liver), $50 \mu \mathrm{L}$ of $\mathrm{FeCl}_{2}(0.5 \mathrm{mM})$ and $50 \mu \mathrm{L}$ of $\mathrm{H}_{2} \mathrm{O}_{2}(0.5 \mathrm{mM})$ were added to form a mixture. After 60 minutes incubation of the mixture, the samples of $0.1 \mathrm{~mL}$ of trichoroacétique acid and $1 \mathrm{~mL}$ of thiobarbituric acid $(0.67 \%)$ were added. The last mixture was heated in boiling water (water bath) for 15 minutes and then cooled. The absorbances were recorded at $532 \mathrm{~nm}$. The inhibitory capacity of the lipid peroxidation products and standards have been determined using the following expression:

$$
\text { Inh } \%=[1-(\mathrm{Ab}-\mathrm{As}) / \mathrm{Ao} \times 100]
$$

As: absorbance substance (extract or standard).

\section{Study of acute toxicity}

The acute toxicity was determinate by the method of OCDE, 2001. Before study of acute toxicity, mice previously fasted for 18 hours are divided into six groups of six mice. They orally received the aqueous extract at doses of 500, 750, 1000, $1500,2000,3000 \mathrm{mg} / \mathrm{kg}$ body weight. The mice were observed for 2 hours, then 24 hours, 48 hours and 72 hours and 10 days after administration.

\section{Phytochemical study}

Phytochemical screening of the decoction of stems with leaves of W. indica was made according to Ciulei method (1982). Chemical groups were identified by liquid medium characterization tests of the extract.

Tannins presence has been highlighted by the reaction of iron chloride test tubes. Flavonoids were characterized by the reaction of shibata reagent. Sterols and triterpenes were identified with Liebermann-Büchard test. Saponins were revealed identified with the observation of persistent foam column. The appearance of a blue or green fluorescence to the UV lamp $365 \mathrm{~nm}$ indicated the presence of coumarins.

\section{Statistical analysis}

The results obtained in this study were expressed as mean \pm SEM. graphPad Prism (version 5.0) was used to analyze the data. Statistical analysis was performed by one way ANOVA followed by Dunnett's test. $\mathrm{P}$ value $<0.05$ was considered as significance compared to control group.

\section{RESULTS}

\section{Anti-edematous effect}

The anti-edematous effect of aqueous extract of stems with leaves of Waltheria indica has been demonstrated at doses of 25, 100, 200, $300 \mathrm{mg} / \mathrm{kg}$ bw (Table 1). In the first hour, edema was significantly reduced $(\mathrm{p} \leq 0.05)$ at a dose of $300 \mathrm{mg} / \mathrm{kg}$ bw. In the third and fifth hour, the aqueous extract at doses of 25, 100, 200 and $300 \mathrm{mg} / \mathrm{kg}$ bw was reduced significantly edema $(\mathrm{p} \leq 0.05)$.

\section{Analgesic effect}

The results in Table 2 shows that extracts of $W$. indica at doses of $100,200,300 \mathrm{mg} / \mathrm{kg}$ bw had significantly analgesic effects $(\mathrm{p} \leq 0.05)$ and dose dependent with inhibition percentages from 36.27 to $54.12 \%$. Paracetamol induced protection $50.40 \%$ against the contractions induced by acetic acid. The analgesic effect of extracts of $W$. indica (at $300 \mathrm{mg} / \mathrm{kg} \mathrm{bw}$ ) was greater than the paracetamol (150 $\mathrm{mg} / \mathrm{kg} \mathrm{bw})$.

\section{Radical DPPH inhibition, lipid peroxidation inhibition and Inhibition of the lipoxygenase}

The aqueous extract had anti-radical effect against DPPH radical with an $\mathrm{IC}_{50}$ of $79.5 \mu \mathrm{g} / \mathrm{mL}$. The antioxidant activity of the extracts of Waltheria indica is very low compared to that of quercetin whose inhibitory concentration is $0.69 \mu \mathrm{g} / \mathrm{mL}$. The lyophilized aqueous extract at a dose of $100 \mu \mathrm{g} / \mathrm{mL}$ prevented the production of lipid peroxide with a percentage of inhibition of $74.31 \%$. The decoction of leafy stems of the plant at $100 \mu \mathrm{g} / \mathrm{mL}$ experimentally inhibited the enzyme lipoxygenase, responsible for the production of leukotrienes enzyme with a high percentage of inhibition of $94.63 \%$ (Table 3).

\section{Phytochemical study}

The results of the phytochemical screening of the decoction of stems with leaves of $W$. indica are shown in Table 4.

Table 1: Anti-inflammatory effects of aqueous extracts of $W$. indica.

\begin{tabular}{|c|c|c|c|c|c|c|c|}
\hline \multirow{2}{*}{$\begin{array}{l}\text { Samples } \\
(\mathrm{mg} / \mathrm{kg} \text { w.b) }\end{array}$} & \multirow[t]{2}{*}{ Doses } & \multicolumn{3}{|c|}{ Increase in paw volume $(\Delta \mathrm{V} \mathrm{ml})$} & \multicolumn{3}{|c|}{ Edema inhibition (\%) } \\
\hline & & $\mathbf{1 H}$ & $3 \mathbf{H}$ & $5 \mathbf{H}$ & 1H & 3H & $5 \mathbf{H}$ \\
\hline Control & $\begin{array}{ll}---- \\
\end{array}$ & $0.27 \pm 0.04$ & $0.38 \pm 0.01$ & $0.44 \pm 0.01$ & --- & --- & --- \\
\hline ASL & 300 & $0.15 \pm 0.02 *$ & $0.16 \pm 0.02^{*}$ & $0.15 \pm 0.01^{*}$ & 44.44 & 57.89 & 84.09 \\
\hline W. indica & 25 & $0.26 \pm 0.00$ & $0.29 \pm 0.01 *$ & $0.24 \pm 0.02 *$ & 03.70 & 23.68 & 45.45 \\
\hline W. indica & 100 & $0.24 \pm 0.01 *$ & $0.30 \pm 0.02 *$ & $0.22 \pm 0.03 *$ & 11.11 & 21.05 & 55.00 \\
\hline W. indica & 200 & $0.24 \pm 0.02$ & $0.23 \pm 0.01 *$ & $0.12 \pm 0.02 *$ & 11.11 & 39.47 & 70.45 \\
\hline W. indica & 300 & $0.11 \pm 0.01^{*}$ & $0.15 \pm 0.01^{*}$ & $0.12 \pm 0.02^{*}$ & 59.26 & 60.52 & 72.73 \\
\hline
\end{tabular}

$\mathrm{n}=6 ;{ }^{*} \mathrm{P}<0.05$ was considered significant compared to the control (analysis ANOVA followed Dunnet's test). 
Table 2: Analgesic effect of aqueous extract of stems with leaves of $W$. indica and paracetamol.

\begin{tabular}{cccc}
\hline Samples & $\begin{array}{c}\text { Doses } \\
(\mathbf{m g} / \mathbf{k g ~ w . b})\end{array}$ & No.of writhes & $\begin{array}{c}\text { Pourcentage } \\
\text { of inhibition (\%) }\end{array}$ \\
\hline Control & --- & $61.17 \pm 2.926$ & --- \\
Paracétamol & 150 & $30.33 \pm 3.56^{*}$ & 50.40 \\
W. indica & 100 & $38.66 \pm 3.78^{*}$ & 36.27 \\
W. indica & 200 & $33.66 \pm 5.01^{*}$ & 44.51 \\
W. indica & 300 & $27.83 \pm 2.99^{*}$ & 54.12 \\
\hline $\mathrm{n}=$ 6;*P <0.05 was considered significant compared to the control (analysis \\
ANOVA followed Dunnet's test).
\end{tabular}

Table 3: Effect of $W$. indica aqueous extract on inhibition of lipoxygenase, lipid peroxidation.

\begin{tabular}{cccc} 
Samples & $\begin{array}{c}\text { Lipoxygenase } \\
\text { inhibition (\%) }\end{array}$ & $\begin{array}{c}\text { Lipid } \\
\text { peroxidation } \\
\text { inhibition }(\%)\end{array}$ & $\begin{array}{c}\text { DPPH } \\
\left(\mathbf{I C}_{\mathbf{5 0}} \mathbf{~ m g} / \mathbf{m l}\right)\end{array}$ \\
\hline W. indica & $94.63 \pm 1.57$ & $74.31 \pm 0.34$ & $1,83.10^{-3}$ \\
Hydrocortisone & $44.28 \pm 5.13$ & nd & nd \\
Silymarin & nd & $54.29 \pm 0.3$ & nd \\
Quercetin & nd & $37.4 \pm 1$ & $6,92.10^{-4}$ \\
\hline
\end{tabular}

nd: not determined.

Table 4: Chemical groups in the aqueous extract of $W$. indica.

\begin{tabular}{ccc}
\hline Chemical groups & Presents & Absents \\
\hline Sterols and triterpenes & + & \\
Tannins and & + & \\
polyphenols & & \\
Flavonoids & + & \\
Alcaloids & + & \\
Anthocyanosids & + & \\
Saponins & + & - \\
Reducing compounds & + & \\
Coumarins & &
\end{tabular}

\section{Acute toxicity}

Acute toxicity study of the aqueous extract of Waltheria indica $\mathrm{L}$. administered in mice by intragatrique way showed any mortality at the highest dose of $3000 \mathrm{mg} / \mathrm{kg}$ weight of the animal.

\section{DISCUSSION}

Waltheria indica is a plant used in traditional medicine to treat inflammatory pathologies. The study assessed the antiinflammatory properties in vivo and in vitro, analgesic, antioxidant and toxicological properties of stems with leaves of this plant.

The evaluation of the anti-inflammatory activity in vivo was conducted using the model of carrageenin-induced paw edema (Winter et al., 1962). Carrageenan induced paw edema in a biphasic phenomenon (Swingle, 1974). The initial phase involves the release of mediators such as histamine, serotonin and bradykin in while the late phase is characterized by infiltration of leukocytes and prostaglandins biosynthesis (Posadas et al., 2004). In this study, a significant edema reduction was observed at the first, the third and fifth hours.

The aqueous extract of stems with leaves of $W$. indica acted as anti-inflammatory drugs in general against endogen mediators such as histamine, serotonin, kinins and prostaglandins (Sanogo et al., 2006). The results of the anti-edematous effects of stems with leaves of $W$. indica confirm the anti-inflammatory activity highlighted work of Vedavathy and Rao (1995) and Rao et al. (2005) on the whole plant. Abdominal contorsions induced by acetic acid injection in the peritoneum of mice was used to evaluate the analgesic properties of the aqueous extract of $W$. indica. Acetic acid injection causes the release of chemical mediators such as serotonin, histamine, bradykinin, prostaglandins and cytokines (Kouakou, 2010). These chemical mediators stimulate peripheral nociceptive neurons and increase vascular permeability (Kouakou, 2010). The aqueous extract preventively administered at doses of 100, 200, $300 \mathrm{mg} / \mathrm{kg}$ reduced significantly $(\mathrm{P}<0.05)$ the number of abdominal writhing in dosedependant manner. The protection of $W$. indica in pain is confirmed by the works of many authors. Rao et al. (2005) reported that the analgesic effect of plant extract was linked cytokines (TNF $\alpha$, IL-12) inhibition. The analgesic effect of $W$. indica extract could be related to the inhibition of the mediators involved in nociception device including cytokines.

Lipoxygenase (LOX) is a key enzyme in the biosynthesis of leukotrienes from arachidonic acid and which are postulated to play an important role in the physiology of several inflammatory diseases (Rackova et al., 2007). Indeed, diverse plant - derived compound have been reported to interfere with LOX product synthesis (Werz, 2007). In vitro study showed that the aqueous extract of Waltheria indica inhibited lipoxygenase activity with a percentage of inhibition of $94.63 \%$. The inhibition of lipoxygenase by the aqueous extract of stems with leaves of $W$. indica has blocked the formation of leukotrienes via arachidonic acid. We suggest that blocking leukotrienes by the aqueous extract of stems with leaves of $W$. indica would have reduced the inflammatory response.

Reactive oxygene species (ROS) are involved at various levels in the inflammatory process. The harmful effects of ROS come from their ability to react with fatty acids, amino acids, proteins, sugars, nucleic acids, resulting in degradation of these molecules with a possible release of toxic substances (Borel, 1988). Thus, the damage of free radicals contributes to the etiology of many health problems such as emphysema, cardiovascular and inflammatory diseases, cataract and cancer (Machlin and Bendich, 1987). However, the antioxidant compounds can neutralize free radicals (Meda et al., 2013). DPPH method used to evaluate the antioxidant capacity of the aqueous extract of stems with leaves of $W$. indica, revealed that its antioxidant capacity was less than quercetin (Table 3). Inhibition of ROS prevents oxidation of membrane lipids leads to the production of arachidonic acid (Meda et al., 2013). The antioxidant effectof the extract of $W$. indica is could contribute to reinforce its anti-inflammatory properties.

The antioxidant activity of aqueous extracts of Waltheria indica has been also evaluated by the inhibition of lipid peroxidation in vitro test. Peroxidation is a phenomenon that can alter the functionality of the membranes (rich in polyunsaturated fatty acids) by altering their permeability and fluidity etc. Model of inflammation induced by carrageenan used in the study by some authors accompanied to increased production of peroxidized lipids 
(Tanas et al., 2010). And also lipid peroxidation was reported as complicating the inflammatory process (Uzkeser et al., 2012). In this study, the aqueous extract of $W$. indica inhibited the lipid peroxidation of rat liver homogenate in vitro (Table 3). These results suggest that the plant could be possessed antioxidant and anti-inflammatory properties. The antioxidant potential of stems with leaves of Waltheria indica could be put to use in the prevention of oxidative stress-related diseases.

The study of acute toxicity of aqueous extract of stems with leaves of Waltheria indica didn't show mice mortality from 500 to $3000 \mathrm{mg} / \mathrm{kg}$ doses. The aqueous extract of this plant was considered to low toxic, according to the scale of Hodge and Sterner (1943) and the WHO (IPCS, 2002).

The phytochemical screening showed that the aqueous extract powder of stems with leaves of Waltheria indica contained tannins, flavonoids, saponins, triterpenes and sterols and anthocyanosides. Several authors have made the relationship between the presence of the compounds of the plants and pharmacological properties including anti-edematous, analgesic, anti-inflammatory, anti-oxidant properties (Bruneton, 2009).

\section{CONCLUSION}

The present study has demonstrated that aqueous extract of Waltheria indica exhibit anti-edemateous, analgesic and antioxidant effects. The study reported lipoxygenase and lipid peroxidation inhibitor effects of Waltheria indica. The data justify the traditional use of Waltheria indica to treat inflammatory diseases.

\section{ETHICAL APPROVAL}

All authors declare that the tests using animals, in this work, were performed according to the protocol approved by the Institute of Health Sciences Research (IRSS, Burkina Faso) and met the international standards of animal study.

\section{REFERENCES}

Adjanohoun, E., Adjakidje V., Ahyi M.R.A, Akoegninou A., d'Almeida J., Apovo F., Boukef K., Chadare M., Gusset G., Dramane K., Eyme J., Gassita J. - N., Gbaguidi N., Goudote E., Guinko S., Houngnon P., Lo I., Keita A., Kiniffo H. V., D. K ,1989. Contribution aux études ethnobotaniques et floristiques en République populaire du Bénin. Agence de coopération culturelle et technique, (A.C.C.T.), Paris, 895 p. Système. [ONLINE] Disponible à l'adresse: http http//www.africamuseum.be , Collections . [Consulté le 09 février 2015].

Bigby $T$ D. The Yin-Yang of 5-Lipoxygenase Pathway Activation. Mol Pharmacol, 2002; 62(2): 200-202.

Borel J-P, Monboisse J-C, Bellon G. Inflammation, collagène et radicaux libres oxygénés. Med Sci (Paris), 1988; 4(5): 304 -10.

Botting R M. Inhibitors of Cycloxygenases: Mechanisms, selectivity and uses. Journal of Physiology and Pharmacology, 2006; 57, Supp 5, 113.124

Bruneton J. 2009. Pharmacognosie, Phytochimie, plantes médicinales, 4e éd., revue et augmentée, Éditions médicales internationals. Tec \& Doc, Paris, France.
Cillard J, Cillard P. 2006. Mécanismes de la peroxydation lipidique et des anti-oxydations. Dossier. OCL VOL. $13 \mathrm{~N}^{\circ} 1$ JANVIERFEVRIER 24-29 p.

Ciulei I. 1982. Practical manuals on the industrial utilization of medicinal and aromatic plants: Methodology for analysis of vegetable drugs. Ministry of chemical industry, Bucharest, ROMANIA. p 67.

Dwyer JH, Allayee H, Dwyer KM, Fan J, Wu H, Mar R. Arachidonate 5 -lipoxygenase promoter genotype, dietary arachidonic acid, and atherosclerosis. New Engl J Med, 2004; 350: 29 - 37.

Flatie T, Gedif T, Asres K, Gebre-Mariam T. Ethnomedical survey of Bretha ethnic group Assosa zone, Benishangul - Gumuz regional state, mid-west Ethiopia. (Medicinal plants reported by household respondents of Berta ethnic group). J Ethnobiology and Ethnomedicine, 2009; 5:14 doi: 10.1186/1746-4269-5-14.

Hodge HC, Sterner JH. Determination of substance acute toxicity by $\mathrm{LD}_{50}$. American Industrial Hygien Association, 1943, 10: 93.

IPCS. The WHO recommended classification of pesticides by hazard and guidelines to classification 2000-2002. IOMC, WHO/PCS/ 01.5, 58: 2-14.

Kerharo, J. \& J. G. Adam. 1974. La pharmacopée sénégalaise traditionnelle. Plantes médicinales et toxiques. Editions Vigot Frères, Paris. $1011 \mathrm{p}$.

Kim KS, Lee S, Lee YS, Yung SH, Park Y, Shin KH, Kim BK. Anti-oxidant activities of the extracts from the herbs of Artemisia apiacea. J Ethnopharmacol, 2003; 85: 69-72.

Koster R, Anderson M, De Beer E. Acetic acid for analgesic screening. Fed Proc, 1959; 18: 412.

Kouakou - Siransi G, Nguessanirie G, Kamena A, Kouakou L, Gressier, Kablan Brou J. Effects of Alchornea cordifolia (Euphorbiaceae) extracts on hydrogen peroxyde produced by stimulated human neutrophils, 17 p.. Système. [ONLINE] Disponible à l'adresse:

http: w.w.w. publication. lecames.org/index.php/pharm/ article/download/.... [Consulté le 07 avril 2015].

Machlin LJ, Bendich A. Free radical tissue damage: protective role of antioxidant nutrients. FASEB J, 1987; 1: 441-5.

Malterud KE, Rydland KM. Inhibitors of 15-lipoxygenase from orange peel. J Agric Food Chem, 2000; 48: 5576-5580.

Meda NTR, Bangou MJ, Bakasso S, Millogo-Rasolodimby J, Nacoulma OG. Antioxidant activity of phenolic and flavonoid fractions of Cleome gynandra and Maerua angolensis of Burkina Faso. J Applied Pharmaceutical Sc, 2013; 3 (02): 036-042.

Miyashiro H, Lim JA, Nakabayashi T, Miyaji M, Hattori M, Shimotohno K. Inhibitory effects of tropical plants on HIV-protease Abstracts of International Conference on AIDS, 1994; 10, 112.

Philpott $\mathrm{M}$ et Ferguson LR. Immunonutrition and cancer. Mutat Res, 2004; 551: 29 - 42.

Posadas I, Bucci M, Roviezzo F, Rossi A, Parente L, Sautebin L, Cirino G. Carrageenan-induced mouse paw oedema is biphasic, ageweight dependent and displays differential nitric oxide cyclooxygenase-2 expression. British Journal of Pharmacology, 2004; 142: 331-338. doi: 10.1038/sj.bjp.0705650

Rackova L, Oblozinsky M, Kostalova D, Kettmann V, Bezakova L. Free radical scavenging activity and lipoxygenase inhibition of Mahonia aquifolium extract and isoquinoline alkaloids. J Inflammation, 2007, 4:15 doi: 10.1186/1476-9255-4-15.

Rao YK, Fang S-H, Tzeng Y-M. Inhibitory Effects of the Flavonoids Isolated from Waltheria indica on the Production of NO, TNF $\alpha$ and IL-12 in Activated Macrophages. Biological \&, Pharmaceutical Bulletin, 2005; 28, 912-915.

Ruffo C K. A. Survey of medicinal plants in Tabora region, Tanzania dans: Traditional Medicinal Plants. Dar Es Salaam University Press - Ministry of Health - Tanzania, 1991; 391 p.

Sanogo R, Maiga A, Diallo D. Activités analgésiques et antiinflammatoires des extraits de Maytenus senegalensis, Stereospermum kuntianum et Trichelia emetica utilisés dans le traitement des dysmenorrhées au Mali. Pharm. Méd. Trad. Afr. 2006; Vol. XIV pp. $123-$ 136. 
Santangelo C, Varì R, Scazzocchio B, Di Benedetto R, Filesi C, Masella R. Polyphenols, intracellular signaling and inflammation. Ann Ist Super Sanità, 2007; 43(4): 394 - 405.

Su X-Y, Wang Z-Y, Liu J-R. In vitro and vivo anti-oxydant activity of Pinuskoraiensis seed extract containg phenolic compounds. Food Chemistry, 2009 ; 117, 681-686.

Swingle K F. Evaluation for anti-inflammatory activity. (Scherrer R A \& Whitehouse M W, eds.) Anti-inflammatory agents, chemistry and pharmacology. New York: Academic Press, 1974; 2: $33-$ 122.

Tanas S, Odabasoglu F, Halici Z, Cakir A, Aygun H, Aslan A, Suleyma H. Evaluation of anti-inflammatory and antioxidant activities of Peltigera rufescens lichen species in acute and chronic inflammation models. J Natural Medicines, 2010; 64(1): 42-49.

Uzkeser H, Cadirci E, Halici Z, Odabasoglu F, Polat B, Tugba NY, Ozaltin S, Atalay F. Anti-Inflammatory and Antinociceptive Effects of Salbutamol on Acute and Chronic Models of Inflammation in Rats: Involvement of an Antioxidant Mechanism Mediators of Inflammation. 2012. Article ID 438912, 10 pages.

Vedavathy S, Rao K N. Anti-inflammatory activity of some indigenous medicinal plants of Chittor district, Andhra Pradesh. Indian Drugs; $1995 ; 32,9,427-432$.

Werz O. Inhibition of 5-lipoxygenase product synthesis by natural coumpound of plants origin. Planta Med, 2007; (13): 1331-1357.

Winter CA, Risley EA, Nuss GW. Carrageenan-induced oedema in the hind paw of rat as an assay for anti-inflammatory activity. ProcSoc Exp Biol Ther, 1962; 111: 544-547.
Zerbo P, Millogo - Rasolodimby J, Nacoulma - Ouédraogo O G, Van Damme P. Contribution à la connaissance des plantes médicinales utilisées dans les soins infantiles en pays San, au Burkina Faso. Int J Biol Chem Sci, 2007; 1(3): 262-274.

Zimmermann M. Ethical guidelines for investigations of expérimental pain in conscious animal. Pain; 1983; 16; 109-110.

Zongo F, Ribuot C, Boumendjel A, Guissou I. Botany, traditional uses, phytochemistry and pharmacology of Waltheria indica L. (syn. Waltheria americana): a review. J Ethnopharmacol, 2013; 148(1):14-26. doi: 10.1016/j.jep.2013.03.080.

\section{How to cite this article:}

Ziebrou MNY, Lompo M, Ouedraogo N, Yaro B, Guissoun IP. Antioxidant, analgesic and anti-inflammatory activities of the leafy stems of Waltheria indica L. (Sterculiaceae). J App Pharm Sci, 2016; 6 (02): 124-129. 